\title{
PUNITIVE-EXEMPLARY DAMAGES IN LABOR RELATIONS LITIGATION
}

\author{
Maxwell Brandwen $\dagger$
}

$\mathbf{M}$ UCH OF the controversy which was generated by the doctrine of punitive-exemplary damages about a century ago has subsided.1 True, some thirty years ago, a study proposed re-examining the effectiveness of the doctrine as a legal tool. ${ }^{2}$ Despite the forceful criticism 3 levelled against it, the doctrine has found a firm footing in our system of law. 4 Only a handful of states have held out against it. 5 Return to this controversy might be regarded as vain, were it not that the doctrine has been

† Member of the New York Bar. A.B., 1917, L.L.B., 1921, Harvard University.

1 The controversy involved Professors Greenleaf and Sedgwick. The former opposed the doctrine, whereas the latter favored it. See Hendrickson v. Kingsbury, 21 Iowa 379, 387 (1866). See also references in Luther v. Shaw, 57 Wis. 237, 238, 147 N.W. 18, 20 (1914).

2 Morris, Punitive Damages in Tort Cases, 44 HaRv. L. Rev. 1173 (1931).

3 The doctrine has been termed "a pernicious doctrine", a "heresy" and a "deformity." Fay v. Parker, 53 N.H. 342, 397 (1873). See also Murphy v. Hobbs, 7 Colo. 541, 5 Pac. 119 (1884). It was termed an "incongruity" and "a sin against sound judicial principle" in Brown v. Swineford, 44 Wis. 282, 286, 288 (1878).

4 It has been followed in at least forty states and in the federal courts. MCCoRMICK, Damages $\$ 78$ (1935) [hereinafter cited as McCormICK]. Sedgwick, Damages $\S 390$ (9th ed. 1912) [hereinafter cited as SEDGWICK]. It is also incorporated in the Restatement of Torts. 4 RESTATEMENT, TORTS $\S 908$ (1939). But cf. "It is probable that, in the framing of a model code of damages to-day for use in a country unhampered by legal tradition, the doctrine of exemplary damages would find no place". McCORMrCK 276 (1935).

5 Massachusetts, Nebraska, Washington, Louisiana, New Hampshire. In Indiana, punitive-exemplary damages may not be awarded if the defendant would be liable to criminal prosecution for the same offense. Stewart v. Maddox, 63 Ind. 51 (1878). A forceful opinion against the doctrine was written in Murphy v. Hobbs, 7 Colo. 541,5 Pac. 119 (1884). This opinion was overturned by subsequent legislation, Colo. REv. STAT. ANN. \$ 41-2-2 (1953). Wisconsin, on the other hand, observes the doctrine, despite its disapproval thereof. The court suggested that the doctrine be rejected by legislation. Brown v. Swineford, 44 Wis. 282 (1878).

"Damages are given as a compensation or satisfaction to the plaintiff for an injury actually sustained by him from the defendant. They should be precisely commensurate with the injury, neither more nor less." 2 GREENLEAF, EvIDENCE 242 (2d ed. 1848). The foregoing rule of damages was quoted with approval in Spokane Truck \& Dray Co. v. Hoefer, 2 Wash. $45,51,25$ Pac. 1072, 1073 (1891). "The damages recovered are measured in all cases by the injury caused. Vindictive or punitive damages are never allowed in this State." Per Holmes, J., in Burt v. Advertiser Newspaper Co., 154 Mass. 238, 245, 28 N.E. 1, 5 (1891).

6 International Union, UAW, v. Russell, 356 U.S. 634 (1958). United Constr. Workers v. Laburnum Constr. Corp., 347 U.S. 656 (1954), involved, inter alia, an award of punitiveexemplary damages, but the court limited its review to whether the National Labor Relations Board had exclusive jurisdiction over the subject matter of a common law tort action. 
extended to labor relations cases in recent years. 6 This development warrants a re-assessment of the doctrine. To direct this study, we rely on the luminous remarks of Mr. Justice Holmes: "So in regard to the formulas of the law, I have found it very instructive to consider what may be the postulates implied. They are generically two: that such and such a condition or result is desirable and that such and such means are appropriate to bring it about."7 Applying those postulates to the present study two salient questions must be faced: is the concept of punitive-exemplary damages a desirable and effective legal tool and, more specifically, does it have any legitimate place in labor relations litigation?

A Texas court recently awarded $\$ 1,265,896$ to twenty-eight former employees who lost their jobs during a strike called by the International Union of Operating Engineers. ${ }^{8}$ The award, in principle, was not unlike that sustained by the Supreme Court of the United States in International Union, $U A W$ v. Russell. 9 In the latter case, plaintiff, a non-striker, claimed that in the course of a strike he was prevented by threats of bodily harm from returning to work for a period of five weeks. A jury awarded him damages of $\$ 10,000$. Five hundred dollars represented lost wages; the remaining $\$ 9,500$ were punitive-exemplary damages. ${ }^{10}$ Twenty-nine similar suits, seeking recovery of approximately $\$ 1,500,000$, awaited the decision in the Russell case.11 The Texas jury and court went farther; they awarded compensatory and punitive-exemplary damages to the twenty-eight plaintiffs. These cases raise anew the thorny issue of the desirability of punitive-exemplary damages as a tool in tort actions.

7 Holmes, Collected Legal Papers 306 (1920).

8 Casida v. International Union of Operating Engineers, Civil No. 10884, D. Tex., March 14, 1962. In another recent case, involving a libel growing out of an industrial dispute, a trial judge awarded general damages of $\$ 100,000$ and punitive-exemplary damages of $\$ 50,000$. Di Giorgio Fruit Corp. v. AFL-ClO. N.Y. Times, November 26, 1961, p.48. However, whether the award be made by jury or trial judge, the force of the criticism of the doctrine remains unimpaired.

9356 U.S. 634 (1958). The Russell case involved the question of exclusive and pre-emptive jurisdiction in the National Labor Relations Board. The majority of the Court held that the state courts could properly award damages for tortious conduct, even though such conduct also constituted an unfair labor practice within the provisions of the Taft-Hartley Act. This paper will not deal with the problem of the respective jurisdiction of the state and federal courts.

10356 U.S. at 652 n.10. Some authorities prefer the simple term "exemplary damages." SEDGWICK 688. Others call them "punitive" or "vindictive" damages. "It seems that the terms exemplary, vindictive, punitive, imaginary, presumptive, speculative and smart money are used in law as synonymous." Hendrickson v. Kingsbury, 21 Iowa 379, 386 (1866). Although the Restatement of Torts uses the term "punitive damages," one of the "comments" uses the term "exemplary damages." $\S 908$, comment (1939). This article will use the term punitive-exemplary damages because of their dual aspect: punishment and an example to others.

11356 U.S. at 657,658 (1958). 
I

Although in the Roman, Civil, and Scottish law, punitive-exemplary damages appear to have been unknown, 12 the doctrine has had a long history in the common law. It stems from the famous eighteenth century case of Huckle v. Money. ${ }^{13}$ In an attempt to suppress John Wilkes' journal, The North Briton, a general warrant, naming no person, was issued by the Secretary of State to arrest printers of the paper. The plaintiff, a journeyman printer, was seized and imprisoned for six hours under the warrant. A jury awarded damages of $£ 300$ against the arresting officer. The defendant, alleging excessive damages, moved for a new trial. In denying this application, Lord Chief Justice Pratt ${ }^{14}$ said:

The personal injury done to [the plaintiff] was very small, so that if the jury had been confined by their oath to consider the mere personal injury only, perhaps $£ 20$ damages would have been thought damages suffcient ... but the small injury done to the plaintiff, or the inconsiderableness of his station and rank in life did not appear to the jury in that striking light in which the great point of law touching the liberty of the subject appeared to them.... I think they have done right in giving exemplary damages. To enter a man's house by virtue of a nameless warrant, in order to procure evidence, is worse than the Spanish Inquisition; a law under which no Englishman would wish to live an hour; it was a most daring public attack upon the liberty of the subject.15

Having affirmed the jury's right to award punitive-exemplary damages, Lord Chief Justice Pratt also acknowledged a limitation on the jury's freedom of action. ${ }^{16}$ This limitation was adopted in a subsequent case ${ }^{17}$ when

12 I Sedgwick 701; Salmond, ToRTs $\$ 33$ (9th ed. 1936). See also Murphy v. Hobbs, 7 Colo. 541, 545, 5 Pac. 119, 122 (1884). Fay v. Parker, 53 N.H. 342, 355 (1873).

132 Wils. K.B. 205, 95 Eng. Rep. 768 (C.P. 1763).

14 Later Lord Camden. At that time, freedom of the press was a burning issue. In another case, Lord Chief Justice Pratt instructed the jury as follows: "I have formerly delivered it as my opinion on another occasion, and I still continue of the same mind, that a jury have it in their power to give damages for more than the injury received. Damages are designed not only as a satisfaction to the injured person, but likewise as a punishment to the guilty, to deter from any such proceeding for the future and as a proof of the detestation of the jury to the action itself." Wilkes v. Wood, Lofft I, 18-19, 98 Eng. Rep. 489, 498-99 (1763). The jury awarded the plaintiff a thousand pounds damages. However, a judge's charge which contained language justifying an award as "a proof of the detestation of the jury to the action itself" was reversed in Hendrickson v. Kingsbury, 21 Iowa 379, 382 (1866). The court, nonetheless, sustained the doctrine of punitive-exemplary damages. See also Lake Shore \& M. So. Ry. v. Prentice, 147 U.S. 101, 106 (1893).

152 Wils. K.B. at 205, 95 Eng. Rep. at 768 . There were in effect fifteen other verdicts which depended on the decision of the court in Huckle v. Money.

16 " $[1] \mathrm{t}$ is very dangerous for the Judges to intermeddle in damages for torts; it must be a glaring case indeed of outrageous damages in a tort, and which all mankind at first blush must think so, to induce a court to grant a new trial for excessive damages." Id. at 207, 95 Eng. Rep. at 769.

17 Beardmore v. Carrington, 2 Wils. K.B. 244, 95 Eng. Rep. 790 (C.P. 1764). The jury awarded damages-principally punitive-exemplary-in the amount of $£ 1000$. 
the court announced the conditions necessary for setting aside a jury's award: "the damages must be monstrous and enormous indeed, and such as all mankind must be ready to exclaim against, at first blush."18 With such vast latitude, however, the restriction on the jury's freedom of action was probably more theoretical than practical.

When the court did not require the jury to confine itself to its "oath to consider the mere personal injury only," it permitted the invasion of the law of torts by concepts commonly associated with criminal proceedings, but not restrained by the traditional safeguards. When the court did not upset an award fifteen times larger than that deemed "sufficient," it sanctioned a novel, free-wheeling doctrine. The explanation must be found in the bitter struggle of the individual against the oppressive measures of George III and his ministers. ${ }^{19}$ Men were battling fiercely to protect their liberty, their privacy, freedom of the press, and freedom from unrestricted search and seizure. The judges who were deeply committed to the supremacy of these principles allowed their strong personal political views to penetrate their judicial decisions. 20

Certain points are worth noting about these early cases. First, they expressly recognized the distinction between compensatory damages ("damages sufficient" or damages which are "a satisfaction to the injured person") and damages awarded specifically as punishment and as deterrent. Secondly, the award of punitive-exemplary damages was predicated on the invasion of primary "constitutional" rights" and not upon malice. In Huckle v. Money, there was no malice in the act of arrest. Indeed, it was effected in the course of defendant's official duty. Moreover, the plainiiff was in custody for about six hours and during that time he was "treated ... well." 22 Originally the infamy of the act itself was the determinant in the

${ }^{18} \mathrm{Id}$. at 250,95 Eng. Rep. at 794 . The verdict was justified by the court on the ground that it was an "extraordinary case which concerns the liberty of every one of the King's subjects." Sedgwick, however, suggests that the refusal of the court to set aside the jury's verdict resulted from "the lack of the power to do so." I SEDGWICK 69. It is interesting to note that prior to making the statement quoted in the text, the court said: "There is not one single case (that is law) in all the books to be found, where the court has granted a new trial for excessive damages in actions for torts." 2 Wils. K.B. at 249, 95 Eng. Rep. at 793. Extremely large awards were not uncommon and were upheld. See Note, 70 HARv. L. REv. 519 (1957).

19 Lord Camden and Chatham, the Elder Pitt, were among the leading libertarians in the House of Lords. One of Lord Camden's earliest cases, as a member of the bar, involved his defense of a defendant accused of publishing a libel. He boldly insisted on the jury's right to judge both the law and the fact, an insistence which to the end of his life he strenuously and at last successfully maintained. 8 Foss, JuDGES OF ENGLAND 358 (1864).

20 The arguments in the House of Lords between Lord Mansfield and Lord Chief Justice Pratt, among others, with respect to judicial decisions in which one or the other participated, reflected a lack of sensitivity and detachment which we have grown to expect from courts. See 3 Campbelt, Lives of the Chief Justices 368-459 (1874).

21 I SEDGWICK 743.

22 Huckle v. Money, 2 Wils. K.B. 205, 206, 95 Eng. Rep. 768, 769 (C.P. 1763). 
award of punitive-exemplary damages. In time, however, a shift in emphasis occurred. The defendant's malice, wantonness, or conscious indifference to harmful consequences-whatever those grab-bag, question-begging epithets may mean-have become the indispensable conditions for an award beyond "damages sufficient."23 The key question posed by this historical development is whether a concept generated by the struggle between an oppressive ruler and his subjects is appropriate in the clash of day-to-day living between individuals in a free and highly complex society; should tort liability based on personal motives and intentions be sanctioned in our turbulent, dynamic society ?24

Those who have canonized the doctrine of punitive-exemplary damages as dogma - and they are in the great majority-do so in great part because it has the weight of authority.25 They also contend that the quantum and severity of admonition or deterrence inherent in compensatory damages are insufficient to assure a stable, secure, and law-abiding society. ${ }^{26}$ Damages must be supplemented when the defendant's conduct is malicious or wanton.27 To buttress their position, the supporters of the doctrine cite those

23 The Restatement of Torts permits the award of punitive damages "to punish . . . for ... outrageous conduct." $\$ 908$ (1939). The subsequent explanation defines "outrageous conduct" as conduct involving "acts done with a bad motive or with a reckless indifference to the interests of others." $\S 908$, comment $b$ at 555 (1939). Punitive-exemplary damages were awarded in a case of trespass to land when the defendant's conduct was such as to disregard "every principle which actuates the conduct of gentlemen ...." Merest v. Harvey, 5 Taunt. 442, 443, 128 Eng. Rep. 761 (C.P. 1814). Such damages are justified in part as serving the function of revenge. Note, 70 HARv. L. REv. 517, 525 (1957). It is difficult to justify any role for revenge in civil proceedings.

24 "[W] other at establishing standards of conduct, we should expect there more than elsewhere to find that the tests of liability are external, and independent of the degree of evil in the particular person's motives or intentions." HoLmes, THE COMMON LAw 50 (1881). "It remains to be proved that, while the terminology of morals is still retained, and while the law does still and always, in a certain sense, measure legal liability by moral standards, it nevertheless, by the very necessity of its nature, is continually transmuting these moral standards into external or objective ones, from which the actual guilt of the party concerned is wholly eliminated." Id. at 38. "[A]ny amount of malevolence on the defendant's part in and of itself would not enhance the amount the plaintiff recovered by a penny, and ... absolute good will would not cut it down." Per Holmes, J., in Burt v. Advertiser Newspaper Co., 154 Mass. 238, 245, 28 N.E. 1, 5 (1891).

25 See Day v. Woodworth, 54 U.S. (13 How.) 362, 371 (1851): "We are aware that the propriety of this doctrine has been questioned by some writers; but if repeated judicial decisions for more than a century are to be received as the best exposition of what the law is, the question will not admit of argument." See also Eshelman v. Rawalt, 298 IIl. 192, 197, 131 N.E. 675,677 (1921).

26 "It goes to prevent the practice of duelling, if juries are permitted to punish insult by exemplary damage." Merest v. Harvey, 5 Taunt. 442, 444, 128 Eng. Rep. 761 (C.P. 1814), cited in Fay v. Parker, 53 N.H. 342, 364-65 (1873). "All damages are in some degree punitive and preventive, but they are not so called unless they exceed just compensation ...." REStatement, CoNTRACTs \$ 342, comment $a$ at 561 (1932). See Prosser, Torts 28 (1941).

27 Although it is generally recognized that the award of damages is essential to avoid the evil of private retribution, the controversy ranges on the quantum of damages. The sup- 
situations where the actual damages may be small but the need for admonition great, as when a man wantonly shoots into a crowd but actually injures no one. A prophylactic end is also served in those cases where one may find it economically advantageous to commit a wrong even though obliged to compensate the innocent plaintiff for the damage done. 28 As a subsidiary ground, it is urged that since an injured plaintiff may not recover all his legal expenses, a "malicious" wrongdoer should not be permitted with impunity to impose such a burden on an innocent plaintiff. 29 It is also urged that a plaintiff might not bring suit unless he could claim punitive-exemplary damages as well. ${ }^{30}$ However, it is principally for the punitive and deterrent effects that the doctrine is supported as a sound, serviceable legal tool. ${ }^{31}$

Despite the repeated ritualistic invocation of the term "deterrence," there is little reliable evidence to establish that punitive-exemplary damages do, in fact, deter. ${ }^{32}$ For example, nothing has been adduced to establish that the extent of wilful tortious conduct is greater in Massachusetts, which has rejected the doctrine, than in New York which has adopted it. It has been generally assumed that such damages are necessary to deter. Yet, one of the least well-charted areas in our modern society is the relationship of punishment to deterrence. Is deterrence myth or reality? Although the subject has occupied the concentrated thought of scholars, psychologists, and penologists for many years, 33 it is still the subject of intense controversy and par-

porters of the doctrine of punitive-exemplary damages contend that such damages are necessary to prevent the evil. The opponents believe that compensatory damages are adequate to serve that principle. "If people would gratify the passion of revenge outside of the law, if the law did not help them, the law has no choice but to satisfy the craving itself, and thus avoid the greater evil of private retribution." Holmes, THE Common LAw $41-42$ (1881). But he rejected the doctrine of punitive-exemplary damages. See note 5 supra. "A civil court in matters of civil injury is a bad corrector of morals; it has only to do with the rights of parties." Baillie v. Bryson, 1 Mur. 317, 337 (1818).

28 See Funk v. Kerbaugh, 222 Pa. 18, 70 Atl. 953 (1908).

29 MCCoRMICK 277.

${ }^{30} C f$. Neal v. Newburger Co., 154 Miss. 691, 700, 123 So. 861, 863 (1929): "Punitive damages are ... . awarded to the injured party as a reward for his public service in bringing the wrong-doer to account." But see Stewart y. Maddox, 63 Ind. 51, 57 (1878).

31 "[T] purposes of exemplary damages are to punish for a past event and to prevent future offenses . ..." 4 REstatement, TORTs $\$ 908$, Comment $e$ at 557 (1939). See also Prosser, TORTS 11 (1941).

32 To demonstrate statistically the efficacy of punitive-exemplary damages as a deterrent may be as difficult as to demonstrate statistically the efficacy of prayer.

33 See, e.g., Report of the Select Committee on CAPITAL Punishment (1930); Royal Commission on Capital PUnishment, Report, CMD. No. 8932 (1953). The latter concluded that peculiar social and economic conditions rather than punishment conditioned the rate of crime. See Koestler, Reflections on HANGing 176 (1956). A recent report of the British Home Office suggests that a deterrent penalty is a much less important factor in murders than many others. 1961 ECONOMIST 326 "I think scientifically the claim of deterrence [in murder] is not worth much. ..." FRANKFuRTER, OF LAW AND MEN 81 (1956).

After four years of research, a traffic research authority concluded that "no amount of 
tisanship. Without entering this controversy, the following observations may be safely made. Some degree of deterrence is probably inherent in compensatory damages. ${ }^{34}$ The quantum, however, is uncertain. What is even more uncertain is the extent of additional deterrence which is socially necessary or desirable and the amount of punitive-exemplary damages necessary to insure that additional deterrence. Thus, three layers of unknown variable quantities underlie the doctrine of punitive-exemplary damages. When one notes that these uncertainties are overlaid by the shifting feelings and sentiments of jurors, one may well be skeptical of the results flowing from the doctrine. 35

Although damages are not ordinarily susceptible to mechanical measurement, experience, common sense, and external tests are helpful. Such tools, however, are of little avail in fixing punitive-exemplary damages. The principle-sufficient to deter but not to oppress-is too shadowy a measure to effect a rational determination of punitive-exemplary damages. 36 The amount may vary from time to time and from place to place. It may depend upon such factors as the mores of the community, different rules of evidence, and the sympathy or distaste for the defendant. ${ }^{37}$ Jurors in a com-

admonishment, no amount of punishment, no type of social censure is an effective deterrent to drunken drivers." Dr. James L. Malfetti, quoted in N.Y. Times, Oct. 9, 1961, p. 37, col. 2.

Difficult as it is to trace the relationship between punishment and deterrence in criminal proceedings, the difficulty is compounded in civil proceedings. Whether a particular state decrees capital punishment for a premeditated murder is fairly common knowledge among the residents of that state. But whether a particular state sanctions punitive-exemplary damages is probably known to few outside the legal profession in that state. For effective deterrence-assuming a nexus between punishment and deterrence-prior awareness of the law is desirable, albeit not always, sufficient. Ignorance of the law, however, may negate deterrence.

34 Restatement, Contracts $\S 342$, Comment $a$ at 561 (1932).

35 The tendency of the law "must always be to narrow the field of uncertainty." HoLmes, The Common Law 127 (1881).

36 "[E]xemplary damages rest upon such vague and unmeasurable bases . . . " Luther v. Shaw, 157 Wis. 234, 237, 147 N.E. 18, 19 (1914). In International Union, UAW v. Russell, 356 U.S. 634 (1958), the trial judge charged: "you are authorized to fix such punitive damages as may seem right to you, not exceeding the amount claimed in the complaint." Record, p. 634. Even McCormick, who accepts the doctrine of punitive-exemplary damages, believes that there should be some control-some external standard-in the award of such damages. MCCORMICK 298. "[T] he dangers of measuring punishment in a civil court are greater than the gains ...." Morris, supra note 2, at 1178. But cf. Note, 70 HARv. L. REv. 517, 531 (1957).

37 Stewart v. Maddox, 63 Ind. 51,57 (1878). The history of fixing damages in cases of fraud and gross negligence in Roman law is of interest here. In those cases, the "plaintiff ... was permitted himself to swear to the amount of injury sustained; and there seems originally to have been no check on this prerogative.... [B]ut this license was restrained by positive provisions, which gave the power of assessment to the judex. To check still more effectually the abuses... various statutory provisions were introduced, and an effort was made to obviate the difficulty by fixed valuations not to be departed from." 1 SEDGWICK 17. The element of caprice and untrustworthiness in damage awards is an age-old problem. 
munity hostile to certain minority groups, to unions, to "outsiders," or to a particular class may award specially large damages against members of such groups. At best, such awards generally are haphazard. That such awards may reflect excesses and injustice rather than reasonable admonition should, therefore, not be surprising.

"Anomalous" 38 as this doctrine is, it has spawned further anomalies by an almost ineluctable process. While an innocent injured plaintiff may claim compensation as a legal right, he has no such right to punitive-exemplary damages, however extreme the defendant's conduct and however meritorious the plaintiff's case. The option is entirely the jury's to award or not to award such damages - to open or not to open Pandora's box. The jury may find overwhelming evidence of wantonness, malice or indifference to consequences; yet it may without any reason refuse to award punitive-exemplary damages. ${ }^{39}$ No judge may deprive a jury of that right.40 This absolute, legally unfettered discretion vested in a jury-tantamount to legally sanctioned anarchy-is rare in our civil procedure.

This condition evidences the invasion of tort litigation by ideas underlying the criminal law ${ }^{41}$ but without the traditional safeguards of criminal procedure.42 Punishment and deterrence are the alleged moving forces in both types of proceedings. Although a jury of twelve men may be trusted as well as a judge to find facts, motive and intent, 43 it is the judge in criminal law who is generally designated to measure the punishment. He is assumed

38 McCoRMICK 291; Morris, supra note 2, at 1176.

391 SEDGwick 753; Harrison v. Ely, 120 Ill. 83, 11 N.E. 334 (1887); Bergmann v. Jones, 94 N.Y. 51 (1883); Hodges v. Hall, 172 N.C. 29, 89 S.E. 802 (1916).

40 "[T] he trier of fact is not required to award punitive damages in a case where they are permissible and it is error for a trial judge to instruct the jury that punitive damages must be given." 4 Restatement, TORTs § 908, Comment $d$ at 556 (1939). See also MCCORMICK 296.

41 The Supreme Court of the United States recognized that punitive-exemplary damages are "penal in [their] nature" to an extent. International Union, UAW v. Russell, 356 U.S. 634 (1958). See also Eshelman v. Rawalt, 298 Ill. 192, 197, 131 N.E. 675, 678 (1921).

42 "Let the criminal law deal with the criminal, and administer punishment for the legitimate purpose and end of punishment-namely, the reformation of the offender and the safety of the people. Let the individual, whose rights are infringed and who has suffered injury, go to the civil courts and there obtain full and ample reparation and compensation; but let him not thus obtain the 'fruits' to which he is not entitled, and which belong to others." Fay v. Parker, 53 N.H. 342, 397 (1873). It is an understatement to call the distinction between punitive and compensatory damages "a modern refinement" as Mr. Justice Stone did in Pizitz Co. v. Yeldell, 274 U.S. 112, 116 (1927). Occasionally, the controversy on punitive-exemplary damages has been described as one of "terminology of the law, rather than as to the extent of the right of recovery or the real measure of damages." Hendrickson v. Kingsbury 21 Iowa 379, 387 (1866). Accord, Brown v. Evans, 17 Fed. 912 (D. Nev.), aff'd., 109 U.S. 180 (1883). But this distinction was recognized as early as Huckle v. Money, 2 Wils. K. B. 205, 95 Eng. Rep. 768 (C.P. 1763).

43 Frankfurter, Of LAW AND Men 82 (1930). 
to be better equipped by training, experience and objectivity. 44 Furthermore, as additional protection to the defendant, the judge's discretion is controlled by, and contained within, fixed bounds set by the legislature, presumably after careful study of the social needs of the community. In the punitive-exemplary damage proceeding, it is the jury who decides, without the benefit of a prior legislative determination, whether punitive-exemplary damages should or should not be awarded and in what amount. Twelve men, deliberating secretly, have the vast power of fixing dollar punishment 45 which in criminal law is left to legislatures and judges. Consequently, each new suit becomes a case of first impression for legislating punishment by each jury. 46 Unlike the legislative bodies which have the benefit of a mass of relevant material and experts in fixing punishment, an ad hoc jury has little more than its feelings and sentiments to guide them. Thus, the doctrine decreeing punishment evades basic safeguards of criminal procedure. Such rough and chaotic justice can be justified, if at all, only by an overriding necessity and outstanding effectiveness. The necessity is problematical; the effectiveness is dubious.

It is urged that a judge can, by his charge to the jury, effectively check a jury's prejudice or abuses. That is expecting too much. The charge generally tends to be an arid abstract proposition of law. Its objectivity-however profuse-rarely illuminates or guides juries. 47 As between an abstract proposition of law couched in conventional text book legal terms and an immediate deep-seated emotional drive, there can be little doubt which will prevail. Individual or local prejudice will not be distracted by an intellectual discourse on abstract legal principles. Crass partisanship can defeat justice and still not be within the cognizance of a judge. The judge cannot give the jury any practicable criterion beyond suggesting that it is for the jury to determine what will be sufficient to punish the defendant and to deter others. That task would be exceedingly onerous and challenging for an outstandingly equipped judge. As Mr. Justice Holmes said in another context: "To

\begin{abstract}
44 "But a judge has wider experience with wrongdoers and is familiar with the normal scope and size of awards. The flexibility which exemplary damages bring to the admonitory function of tort law can better be achieved by the judge than by the jury." Note, 70 Harv. L. REv. S17, 530 (1957). But even judges have been criticized for the erratic character of their sentences for comparable crimes. So serious is the situation that the United States Attorney General felt it necessary to point out that inconsistent sentences are "inflaming" rather than "healing" the underlying social "cancer" that leads to organized crime. N.Y. Times, Oct. 13, 1961, p. 21.
\end{abstract}

45 See Fay v. Parker, 53 N.H. 342 (1873).

46 Stewart v. Maddox, 63 Ind. 51 (1878). The plaintiff's complaint sets the limits of damages. This is a modified throwback to early Roman law when the plaintiff himself was permitted to swear to the amount of injury sustained. See note 37 supra.

47 FrANKFuRTER, op. cit. supra note 43 , at 83 . The judge's charge on punitiveexemplary damages in the Russell case, running to about a thousand words, was so general that it might have been taken baldly from a treatise on damages. Record, pp. 631-33. 
measure them justly needs not only the highest powers of a judge and a training which the practice of the law does not insure, but also a freedom from prepossessions which is very hard to attain." 48 Yet the doctrine expects such "powers" and "training" and "freedom from prepossession" from an ad hoc jury of twelve men.

It is also urged that a court may reverse a jury's award when, in its opinion, it is excessive.49 Although judges have not.gone so far as Lord Chief Justice Pratt, who would reverse only if the damages were so "monstrous and enormous indeed, and such as all mankind must be ready to exclaim against, at first blush," 50 still reversals are rare. 51 More often than not, jury awards of such damages are deemed oracles and sacrosanct, and are rarely modified.

Further, it has been suggested that a plaintiff might not bring suit unless he could claim punitive-exemplary damages also. 52 But stability in social and economic relations should not require the encouragement of private litigation or private prosecutors. 53 If a public prosecutor does not choose to

48 Holmes, Collected Legal Papers, 129 (1920). See also Cohen, Reason and Nature, 420,421 (1921), where he wrote: "The obvious fact which no glorification of law can obscure is that it is made by human beings subject to the limitation of human ignorance and of inadequate sympathy or good will .... History does not show that the partisan bias of limited group experience can always be removed by legal training or by the criticism of the legal profession."

49 "The danger ... of immoderate verdicts, is certainly a real one, and the criterion to be applied by the judge in setting aside or reducing the amount is concededly a vague and subjective one." McCormick 278.

so See note 17 supra.

51 See Luther v. Shaw, 157 Wis. 234, 237, 147 N.W. 18, 19 (1914). On the issue of the character of jury awards of punitive-exemplary damages, statements by text writers cover a wide spectrum. On the one hand: "The reported cases offer many interesting instances of startlingly large verdicts for punitive damages, and the function of judicial review of the jury's 'rough justice,' as meted out under its punitive power, must in general be one of considerable difficulty." MCCORMick 278. But he says that unjustifiable awards rarely "escape correction." Ibid. "The amount of damages which may be assessed in a proper case under the head of exemplary damages is in a measure arbitrary. The jury may do what they please, and their verdict is subject to revision only in case of a palpable miscarriage of justice." 1 Street, Foundations OF LEGal LiabiLITY 488 (1906). A verdict which barely exceeded the actual damages was reversed. Mitchell v. Randall, $288 \mathrm{~Pa}$. 518, $137 \mathrm{Atl}$. 171 (1927). A verdict which was many times the actual damages was sustained. Lampert v. Judge \& Dolph Drug Co., 238 Mo. 409, 141 S.W. 1095 (1911). That such an anarchical doctrine should yield disharmony is inevitable.

52 Note, 70 HARv. L. Rev. 517, 525, 526 (1957).

53 "Perhaps, the principal advantage [of punitive-exemplary damages] is that it does tend to bring to punishment a type of cases of oppressive conduct, such as slanders, assaults, minor oppressions, and cruelties, which are theoretically criminally punishable, but which in actual practice go unnoticed by prosecutors occupied with more serious crimes." McCoRmick 276. "If an act is particularly wrongful, society imposes criminal sanctions in order to deter the wrongdoer and others from repeating the offense. But while some faults, such as ordinary negligence, should be discouraged, they do not warrant the stigma and severity of criminal punishment." Note, 70 HARV. L. REv. 517, 523 (1957). The difficulty 
proceed by criminal process in a particular situation, either because it is too trivial or because he is occupied with more serious crimes, his decision, rather than that of a private plaintiff might well prevail. If a conscientious and dedicated prosecutor thinks that the threat to the well being of the community from particular conduct is too slight to warrant protective criminal action, his decision should not be negated or overruled by a private plaintiff whose decision may be determined primarily by zeal for personal gain rather than protection of society. At all events, the burden of establishing the social utility of private prosecution must be borne by the supporters of the doctrine. This burden has not been discharged.

This aspect of the problem would not merit such attention if it had not been suggested that,

Although in practice it may not always be possible to avoid excessive punishment, the risk of such punishment is outweighed [sic] by the likelihood that the reluctance of prosecutors to press charges for minor offenses would allow some wrongdoers to escape adequate punishment if exemplary damages were abolished. 54

There is no sound reason to suppose that the only choices are either no punishment or excessive punishment for minor offenses. If, however, these were the only choices-and they are not, as we shall see later-much could be said for permitting minor offenses to go unpunished rather than risking excessive punishment whether in many or few cases. Such a choice would appear to be more 'consonant with traditional concepts of justice than the converse. Minor offenses scarcely necessitate a slavish adherence to a doctrine which stemmed from the deprivation of an individual's revered rights. There is no need to use a tank to crush a mouse.

Furthermore, the doctrine "seems to be the only practice (apart from the double and triple damage statute cases)" in which jury awards result in "an out and out windfall to the plaintiff." 55 Even under those multiple damage statutes, before damages may be doubled or tripled, actual base damages must be initially ascertained.56 Such base damages are compensatory and are founded on a record susceptible to evaluation and not on undisclosed feelings and sentiments. Moreover, the punitive damages are defined and limited. Con-

with this position is that even though "ordinary negligence should be discouraged," it should not be the basis for punitive-exemplary damages. If the wrong is more serious than ordinary negligence, and if no criminal prosecution is warranted, why give a jury this practically uncontrolled latitude of fixing punishment?

54 Note, 70 HARV. L. REv. 517, 525 (1957).

s5 Morris, supra note 2, at 1177 n.7. The statutory device of double or triple damages is used in nearly every state. It has a history of many centuries. See Note, 70 HARV. L. REv. 517,518 (1957).

56 Occasionally the actual damage sustained by plaintiff may be greater than he can establish in court. In such cases, the additional damages make up for that inability. Mathey v. United Shoe Mach. Corp., 54 F. Supp. 694, 702 (D. Mass. 1944). 
sequently, the opportunity for caprice and prejudice in those situations is materially circumscribed. In the absence of those statutes which legislatures deemed of special public interest, it is difficult to understand why instituting an action should warrant a windfall. In those circumstances, compensating a plaintiff fully should be adequate. It is questionable whether the public interest requires further rewards. 57

It is urged that a special class of cases require remedial action beyond purely compensatory damages. They include cases in which the loss to the plaintiff is small but the wrong particularly offensive. In another group of cases, a defendant may find it more profitable to commit and pay for the wrong. 58 True, the compensatory damages in those cases may be too slight to warrant the expense of instituting an action or ineffective to prevent a repetition of the wrong. Here, as in the case of the minor offenses referred to above, a solution is provided by the so-called Connecticut rule. 59 According to that rule, if the elements indispensable for the award of punitive-exemplary damages are present, the defendant is taxed with all the legal expenses of the injured plaintiff over and above taxable costs. This rule would have a double virtue; it would punish wanton wrong doing while restricting the area of caprice and prejudice open to juries. It would serve to bring a rough, potent legal tool within controlled bounds. If punishment, indeed, deters, then the imposition of such additional burden on the wanton wrongdoer would not be without utility. Moreover, if the offense be minor, such additional burden on the defendant would in all likelihood provide adequate punishment. Litigation would not be encouraged for the sake of windfalls, confusion would be restricted, and a semblance of coherence would be attained. A measure of relief would be available in those cases in which the plaintiff's loss is slight but which require remedial legal action beyond what is now afforded in ordinary tort actions. It would

57 "The manifest iniquity of awarding plaintiff something to which he is not entitled." Murphy v. Hobbs, 7 Colo. 541, 550-51, 5 Pac. 119, 125 (1884). Punitive-exemplary damages have been "condemned as undue compensation of the plaintiff beyond his just desserts in the form of a criminal fine which should be paid to the state if anyone..." See Prosser, TORTS 13 (1941).

A contrary view is justified as follows: "Awarding exemplary damages to the state might permit the jury to take a more objective view of the defendant's motives and conduct, divorced from sympathy or distaste for the plaintiff. However, the subsidiary functions of exemplary damages-compensation and revenge-seem to justify making the award to the plaintiff even though it may be largely a windfall." Note, 70 HARv. L. REv. 517, 525 (1957). Anti-trust cases may be cited as an example of private individuals supplementing the activities of public prosecutors. But such cases are not ordinarily minor. And, more importantly, such litigation has been expressly declared to be so much in the public interest that a specific and limited reward is fixed for successful prosecution.

58 See note 28 supra.

59 Craney v. Donovan, 92 Conn. 236, 102 Atl. 640 (1917); Doroszka v. Lavine, 111 Conn. 575, 578, 150 Atl. 692, 693 (1930). "Much may be said for the practical common sense of this restriction..." MCCORMICK 297. Connecticut has a statute authorizing double damages in accident cases involving violations of certain traffic laws. CONN. GEN. STAT. REY. \$ 14-295 (1958). 
also satisfy the emotional drive of those plaintiffs who do not choose to depend on a public prosecutor or police force to bring a defendant to book without exposing such defendant to excessive punishment or unbridled caprice.

II.

The second of the two questions posed at the outset of this paper must now be examined: does the doctrine have any legitimate place in litigation involving labor relations? An answer is facilitated by noting the existing exceptions to the enforcement of the doctrine. According to the Restatement of Contracts, "punitive damages are not recoverable for breach of contract." 60 A leading authority expresses the rationale of this conclusion as follows:

The denial of such recovery in cases of contract probably flows first from a desire to restrict the field of exemplary damages, the allowance of which is usually regarded as an anomaly, and, second, from a belief that, since the vast majority of breaches of contract are due to inability or to erroneous beliefs as to the scope of the obligation, it is doubtful wisdom to add to the risks imposed on entering into a contract this liability to an acrimonious contest over whether a breach was malicious or fraudulent and the danger of a large and undefined recovery of punitive damages. ${ }^{61}$

If it is doubtful wisdom to expose parties to a contract to "the danger of a large and undefined recovery of punitive damages," it would seem even more doubtful wisdom to do so in the case of an employer and his workers and their representatives. A commercial contract does not ordinarily have the quality of continuity and personal relationship present in a labor-management situation.

It has been said that "the general purpose underlying the law of damages, whether they are given for a breach of contract or for a tort, is to promote security and to prevent disorder." 62 Yet, if the attainment of those ends does

$60 \S 342$, at 561 (1932).

61 MCCorMICK 291. One court refused to award punitive-exemplary damages for the defendant's breach of contract to pay a money debt, even though this defendant sought to embarrass the plaintiff financially and to affect its credit standing. J. J. White, Inc. v. Metropolitan Merchandise Mart, Inc., 48 Del. 526, 107 A.2d 892, (1954). See also 5 CorBin, Contracts $\S 1077$ (Supp. 1961, at 48). Cf. Note, 70 HARv. L. Rev. 517, 532 (1957): "Since a malicious breach of contract may be as wrongful and deserving of punishment as an intentional tort, allowing exemplary damages would have the socially desirable effect of discouraging such breaches of contract." The author of the Note supports the award of punitiveexemplary damages in such cases on the ground that injury to the plaintiff may exceed the recoveries under the usual contract theories of damages. That view might be defensible if punitive-exemplary damages were limited (in that case) to an amount necessary to compensate. But the function of punitive-exemplary damages is not so limited.

625 CoRbin, Contracts 366 (1951). Occasionally, punitive-exemplary damages are awarded in cases where the breach of contract duties is also a tort. See Prosser, The Borderland of Tort and Contract, in SELECTED TOPICS ON THE LAW OF TORTS 380, 402, 420 (1953). "The damages that are called punitive in breach of promise cases can generally be properly regarded as compensatory. They are given as compensation for kinds of harm that cannot easily be estimated in terms of money." 5 CORBIN, CONTRACTs 369. See also Luther v. Shaw, 157 Wis. 231, 147 N.W. 17 (1914); Note, 70 HaRv. L. REv. 517, 531 n.103. 
not require the award of punitive-exemplary damages for breach of contract, one may ask why they are required in tort actions. This question is even more pertinent when one notes that the law of torts goes beyond that of contracts in carving out exceptions-exceptions even in the area of compensatory damages. A distinguished authority in the field of torts expressed this rationale as follows: "[T] he primary conception of the obligation in torts is to refrain from injurious action, unless the doing of the act, even with its attendant risk, is so beneficial to the public generally, the object of it so valuable to the general welfare, that even private injury must be borne to encourage it." 63

In the service of valuable public welfare, one is privileged knowingly to infict temporal damage.64 Since, in such a situation, compensatory damages are denied, punitive-exemplary damages are also barred.

The sturdy, indeed phenomenal, growth of our modern economic system has occurred in a climate characterized by the struggle between management and labor. Some harm is an unavoidable by-product of such conflict and the loss is allowed to lie where it falls. 65 "[E]conomic loss inevitably attends work stoppages." 66 Indeed, the pervasiveness of this struggle coupled with the vital need for stability in labor-management relations necessitated intervention by the Congress in balancing the competing claims of management and labor. Congress has chosen to subordinate its concern with an employer's economic loss to the protection of workers' rights to bargain collectively and to strike. Fearful of chaos, Congress has set up an elaborate regulative scheme watched over by a special administrative agency. Rights, duties, privileges, prohibitions and procedures were spelled out in considerable detail. By these measures, Congress sought in an orderly fashion to limit the impact of the struggle, to expedite the disposition of labor disputes, and to insure uniformity of results. 67

The necessity of federal legislation is dramatically evidenced by the Russell case. A strike was called. The union involved was one of the leading responsible labor organizations in this country. One may reasonably assume that the strike, in the opinion of the union, was called in the best interests of its members.

63 BOHLEN, STUdIES IN THE LAW OF TORTS 62 (1926).

${ }^{64}$ The existence of the privilege and how far it shall be allowed are matters of legislative policy. See Holmes, Collected Legal Papers 119 (1920).

65 This was recognized by Congress when it passed the Clayton Act, in answer to those who sought to make labor unions subject to the provisions of the Sherman Anti-Trust Act. 38 Stat. 730 (1914) 15 U.S.C. $\$ \$ 1-12$ (1958). In a strike, immunity is won by its purpose. See Frankfurter \& Greene, The Labor Injunction 25 (1930).

66 International Union, UAW v. Russell, 356 U.S. 634, 649 (Chief Justice Warren, dissenting).

67 "The Federal Act represents an attempt to balance the competing interest of employee, union and management," said Chief Justice Warren dissenting in Russell. Id. at 650. "Iחn the eye of the law [that price is] thought sufficient to justify the harm ...." Exchange Bakery \& Restaurant, Inc. v. Rifkin, 245 N.Y. 260, 263, 157 N.E. 130, 132 (1927) (per
Andrews, J.). 
The strikers sought to make their strike effective by attracting as many adherents to their point of view as possible and keeping as many non-strikers as possible away from the plant. If enough workers returned to permit uninterrupted production, the strike might fail. Had the strikers limited themselves to peaceful persuasion, and had the non-strikers stayed away from the plant, or had the employer shut down the plant, then no worker could have recovered damages for loss of wages. Neither could the employer have recovered anything, even though it could demonstrate economic loss as a result of the strike. ${ }^{68}$ But the jury found evidence of intimidation and threats of violence on the part of some strikers against some non-strikers. ${ }^{69}$ Such threats, being unlawful, gave rise to legal liability. They annulled the privilege to cause temporal damage to non-strikers.

Russell, a non-striker seeking to return to work, was deprived of the privilege of working for five weeks. He lost $\$ 500$ in wages. He was entitled to be made whole, that is, to recover the wages which he lost, but he was awarded $\$ 10,000: 70$ compensation five per cent; punishment and deterrence ninety-five per cent. Thus, he received a "windfall" of $\$ 9,500$, the equivalent of almost two years' wages. Despite the defendants' objections, the Alabama Supreme Court justified the award in the light of "the necessity of preventing similar wrongs ... [as] we must do ....'71 Yet other legal tools-more appropriate and swifter-were readily available to prevent similar wrongs without oppressing defendants or unjustly enriching plaintiffs. The majority of the United States Supreme Court sustained the Alabama court's holding without more than "punitive damages constitute a well-settled form of relief under the law of Alabama when there is a willful and malicious wrong."72 Chief Justice Warren, in his dissenting opinion, argued that the award of damages in a state court frustrated the policies of Congressional legislation and had "an unfavorable effect upon the uniformity the Act sought to achieve." He added:

By approving a state-court damage award for conduct regulated by the Taft-Hartley Act, the majority assures that the consequences of violating

$68 \mathrm{It}$ is assumed-and there is no evidence to indicate the contrary-that the strike was not in violation of a contractual obligation.

69 Apparently there was no evidence of any personal injury.

70356 U.S. at 652 n.10.

71264 Ala. 456, 473, 88 So. 2d 175, 189 (1956). Yet an employee who is wrongfully discharged is "entitled [only] to the full wages promised less what he can eam in similar service by reasonable effort after his discharge." 5 CORBIN, CONTRACTs 167 (1951).

An employee who was wrongfully discharged was disallowed punitive-exemplary damages. Holland v. Spartanburg Herald Journal Co., 166 S.C. 454, 165 S.E. 203 (1932). "[A]cts of willfulness will support punitive damages in tort cases . . . but will not in suits arising $e x$ contractu, ... and especially in breach of contract cases, although in such cases the voluntary breach is of necessity an act of volition. ..." Id. at 469, 165 S.E. at 208. Corbin suggests that a larger compensatory award might be sustained. 5 CorBIN, CoNTRACTs $\$ 118$ (1951).

72356 U.S. at 646. 
the Federal Act will vary from State to State with the availability and constituent elements of a given right of action and the procedures and rules of evidence essential to its vindication. The matter of punitive damages is an example, though by no means the only one. ${ }^{73}$

We are not here dealing with the respective roles of state and federal jurisdiction or the virtues of uniformity. Neither are we evaluating the role of trade unions in our society. We are concerned for the moment only with the legitimacy of the doctrine of punitive-exemplary damages in a tense, feverishly disturbed labor-management situation. This demands awareness of and obeisance to the complexity of human motives and the clash of interests in a strike. On one side are workers struggling to protect their jobs and improve their standards. On the other is the employer who seeks to keep costs down and to maintain or improve his competitive position. Also, there are the non-strikers whose paramount concern is the possible loss of wages. Thus, there are three parties intimately and directly involved, participating, and clashing -in one form or another-in a strike.

A strike presents the mystery of human dilemmas. The non-striker must choose between losing his wages or returning to work. Should he choose to return he must know that his conduct may impede the objectives of the strikers. He is unlike the innocent and passive bystander in the crowd into which a wanton wrongdoer shoots. By his affirmative choice to return to work, he, in effect, sides with the employer and, psychologically speaking, provokes the strikers. The privilege or liberty to return to work remains unimpaired, 74 but provocation is a natural result of his conduct. Scabbing to a striker is as much a provocation as the proverbial red flag to the bull.

That strikers will respond to the hostile action of the non-strikers is natural, reasonable, and inevitable. What is uncertain is the nature of the response. Here the strikers too face a dilemma. Will their response be limited to a reluctant passive acceptance of the non-strikers' return to work which may defeat the strike? If peaceful persuasion be not effective, will the urge to make the strike succeed become so obsessive as to cause strikers to resort to minatory tactics? Dilemmas in a strike are not always met with detachment and reason, despite any instructions from top union leadership to exercise restraint.

In a strike, it is not uncommon for tempers to flare and emotions to rise to frenetic heights. It is the rare judge who sees that "men become earnest and excited and vigorous at such times. ... The fervor of argument is upon them. ... They forget etiquette and grammar; ... instigated by ... deep convic-

73356 U.S. at 650-51. In a recent decision, it was held (three judges dissenting) that the Taft-Hartley Law does not provide for punitive-exemplary damages for collective bargaining contract violations. United Shoe Workers of America v. Brooks Shoe Mfg. Co., Wall St. Journal, p. 5, Jan. 5, 1962.

74 "No one should forget that to have a right is not the same thing as having a right to insist on that right." Lewis, Legal and Moral Responsibility, THE LISTENER 645 (1961). 
tion men always employ strong words-the nomenclature of the strike is not the language of the parlor."'75

Apparently the trial judge in the Russell case was not one of those "rare judges" who are aware of the bitterness, the partisanship, and the passions of a labor controversy. Presumably forgetting that parties in a strike are something less than saints, he instructed the jury that if "the defendant was actuated by malice and actuated by ill-will, committed the unlawful and wrongful acts alleged, you, in addition to the actual damages, if any, may give damages, for the sake of example and by way of punishing the defendant for the purpose of making the defendant smart. . . ."76 It transcends human nature and conducf for strikers to be actuated by anything other than "ill-will" against a nonstriker seeking to return to work and thereby imperiling the hopes of the strikers. To expect any other emotion from strikers is to expect a miracle. The very atmosphere of a strike seethes with strife and ill will-striker pitted against non-striker, striker against employer, and employer against striker. Yet not a word of this drama was included in the judge's charge. Instead, he charged the jury that malice could "be implied from the intentional doing of the wrongful act." $77 \mathrm{He}$ sanctioned this implication despite the grave doubts that the acts of the strikers were committed out of pure malice and spite. ${ }^{78}$ The contrary implication may be more reasonable. The action of a striker, passionately and sincerely determined to elevate his standards and to prevent a nonstriker from returning to work, is generally a far cry from ordinary wanton conduct. It may be unlawful, but it is neither necessarily nor implicitly wanton, malicious, or spiteful. Indeed, in many cases, the strikers may be animated not exclusively by personal interest but also by the urge to help all the workers in the plant, including the non-strikers. That the latter disagree or do not welcome such offer of help does not negate these motives of the strikers. 79 In any event, the issue is not so simple or plain that it warrants without more a

75 Wood Mowing \& Reaping Mach. Co. v. Toohey, 114 Misc. 185, 189, 186 N.Y. Supp. 95, 98 (Sup. Ct. 1921).

${ }^{76}$ Record, p. 631. (Emphasis added.) When the term malice is used, it is meant to signify "that the harm is wished for its own sake, or, as Austin would say with more accuracy, for the sake of the pleasurable feeling which knowledge of the suffering caused by the act would excite." HOLMEs, THE COMmON LAW 52 (1881). "I mean by malice, a malevolent motive for action, without reference to any hope of a remoter benefit to oneself to be accomplished by the intended harm to another." Holmes, Collected LeGal PAPERs 118-19 (1920).

77 The extent of the unawareness of the trial court judge of the complex elements in a strike is evidenced by the instruction which he gave at the plaintiff's request. "Malice may be implied from the intentional doing of a wrongful act; and if you are reasonably satisfied from the evidence that the defendants intentionally committed the wrongful acts charged in the complaint then I charge you that said acts were maliciously done-and you may award punitive damages." Record, p. 634.

78 See note 76 supra.

79 See Exchange Bakery \& Restaurant, Inc. v. Rifkin, 245 N.Y. 260, 263, 157 N.E. 130, 132-33 (1927). 
Euclidian conclusion that an intentional wrongful act is ipso facto also malicious. The problem is sufficiently complex to require a deep understanding of the motives underlying the acts. Without this empathy, justice is sterile.

One further fact must be noted. Strikes generally are settled after a time and strikers and non-strikers return to work. What kind of harmony or stability can the employer expect from returning strikers when they are to work with non-strikers who have cost their union and a fellow officer large punitiveexemplary damages? This situation does not contribute to the stable, secure, and law-abiding society which the doctrine of punitive-exemplary damages is supposedly designed to further.

It has been suggested that exceptions have been carved out of the doctrine of punitive-exemplary damages. ${ }^{80} \mathrm{We}$ come now to an exception in ordinary tort litigation well-established in the very states which adhere to the doctrine. When two parties scrap, the fever and ill-will not infrequently engendered by and associated with such squabbles are overlooked for purposes of determining punitive damages. Such feelings are not ignored when one is injured suddenly and without provocation by a "malicious" wrongdoer.

As Sedgwick, one of the most vigorous supporters of the doctrine, stated it: "The existence of provocation, though it may not be a defence, will prevent the allowance of exemplary damages. ... So in an action of assault and battery the fact that the injury was inflicted during a mutual fight will prevent the allowance of exemplary damages." 11 Certainly, strikes afford vivid examples of "a mutual fight" between strikers and non-strikers.

Sedgwick adds that the provocation "must have been so recent that the act can be said to have been committed under the immediate influence of feelings excited. ... . And it must have been sufficient to have stirred some degree of resentment in an ordinary man."82

Mr. Justice Holmes' lapidary wisdom may also come to our assistance at this point. He said: "According to current morality, a man is not so much to blame for an act done under the disturbance of great excitement, caused by a wrong done to himself, as when he is calm. The law is made to govern men through their motives, and it must, therefore, take their mental constitution into account." 83

In the Russell case, provocation was recent; indeed, it was contemporaneous; feelings of resentment were stirred, as they would be "in an ordinary

${ }^{80}$ See pp. 472-73 supra.

81 I SEDGwick 747. Huftalin v. Misner, 70 Ill. 55 (1873). See Brown v. Swineford, 44 Wis. 282,290 (1878).

82 I Sedgwick 749. See also SutherLand, Damages $\$ 1258$ (1916). Note the meticulous phrasing in the following quotation from Chief Justice Warren's dissenting opinion in the Russell case: "The unprovoked infliction of personal injuries during a period of labor unrest is neither to be expected nor to be justified, but economic loss inevitably attends work stoppages." 356 U.S. at 649 . (Emphasis added.)

83 Holmes, THE COMmON LAW 61 (1881). 
man." The acts of the strikers were sparked by what they conceived to be wrongs done to them. All the elements essential to bar punitive-exemplary damages appear to have been present in the strike in the Russell case. Although the strikers, in the circumstances, could not have properly pleaded provocation as a defense to an action for compensatory damages, they would have been entitled to allege and show provocation as a bar to the award of punitiveexemplary damages. The jury in the Russell case was not adequately instructed on that point. ${ }^{84}$ Had provocation been demonstrated, that alone might well have averted an oppressive judgment on the defendants and a windfall for the plaintiff. 85

The vice of the doctrine is deepened when we note that twenty-nine other suits were brought against the union for similar activities in the Russell strike. All sought punitive-exemplary damages, 86 aggregating approximately $\$ 1$, 500,000 . Some resulted in punitive-exemplary damage awards. Others were awaiting the decision of the United States Supreme Court. The multiplicity of suits raises the question whether punitive-exemplary damages may be awarded to a number of plaintiffs for what is substantially the same objectionable conduct. Intimidation or threats of violence to each non-striker are a separate wrong, and separate liability for compensation arises in each case. However, since the underlying purposes of the doctrine are punishment and deterrence, the real party in interest is the public and not each individual plaintiff. Since the gravamen or gist of the continuing conduct complained of is, in substance, the same, the doctrine would appear to be fully served by assessing punitiveexemplary damages on the basis of conduct rather than on the fortuitous number of plaintiffs. Conduct may be aggravated by the number of people affected thereby, but not necessarily in a precise mathematical fashion determined by the number of plaintiffs. Consequently, when the trial judge in the Russell case charged "that the amount of the [punitive-exemplary] damages should not be

84 Although the judge in his charge to the jury briefiy referred in another context to the fact that provócation may be of a kind "sufficient to prevent an award of exemplary damages," he did not elaborate or deal with it in a sufficiently explicit manner. Record, pp. 630, 631,633 . In the circumstances, one may doubt whether the jury gave adequate consideration to the question of the sufficiency of such provocation to generate the particular response from the strikers. See Brown v. Swineford, 44 Wis. 282, 289, 290 (1878).

85 In labor relations cases, a large award of punitive-exemplary damages soon becomes known in labor-management circles. Thus, in the very situation in which the propriety of applying the doctrine is most open to question, deterrence can be most effective. Indeed, it may be so effective as to interfere with and even paralyze legitimate activities. Yet if the doctrine continues to be sanctioned in industrial disputes litigation, unions may have to resort to insurance protection against such hazards and deterrence may lose its vigour. See Employers Ins. Co. v. Brock, 233 Ala. 551, 172 So. 671 (1937); American Fidelity \& Casualty Co. v. Werfel, 230 Ala. 552, 162 So. 103 (1935). A curious result may follow. Those who are most likely to be deterred may protect themselves, whereas the individual entirely unaware of the doctrine, will neither be deterred by nor insured against that hazard.

86 In Russell, each of the plaintiffs in the thirty suits sought damages of $\$ 50,000$. In two cases, awards of $\$ 10,000$ were made and in a third case, the award amounted to $\$ 18,450$. 356 U.S. at 657. 
diminished" because there were many other similar suits pending against the defendants, 87 he was demonstrating one of the most oppressive excrescences of the doctrine. Even in criminal law, when a defendant has been convicted of more than one crime, the judge has the option of mitigating or intensifying the punishment by ordering sentences to run concurrently or consecutively. ${ }^{88}$ But the jury, the sentencing agency in the Russell case, was denied the choice of diminishing individual punitive awards when the same objectionable conduct affected more than one person. Punitive-exemplary damages to each of twenty-nine plaintiffs may spell harsh oppression rather than reasonable admonition. Windfalls are bountifully distributed and substantially beyond the needs of deterrence. Excessive multiplication may defeat justice. 89 When a most powerful weapon is used in this manner, on one side of an intense social struggle, skepticism regarding law's fair dealing is to be expected.

This result is particularly unfortunate when liability is imposed on a principal. According to Sedgwick,

it is the better opinion that no recovery of exemplary damages can be had against a principal for the tort of an agent or servant unless the defendant expressly authorized the act that was performed or approved it, or was grossly negligent in hiring the agent or servant, or in not preventing him from committing the act.... The burden of showing authorization or approval by the principal is on the plaintiff.90

87 The plaintiff requested the court to charge the jury "that the amount of the damages awarded should not be diminished because of the fact that a number of other persons have filed similar suits against the defendant, which suits are pending and undisposed of." The court gave the requested charge. Record, p. 636. Punitive-exemplary damages have been allowed to more than one plaintiff as a result of one actionable wrong. See Reutkemeier v. Nolte, 179 Iowa 342, 161 N.W. 290 (1917).

However, the need for reducing the amount of punitive-exemplary damages in such multiple situations was recognized in Luther v. Shaw, 157 Wis. 234, 147 N.W. 18 (1914). The court in that case said: "Had the learned circuit judge not cut down the verdict for exemplary damages we would no doubt have reduced it considerably below the sum fixed by the circuit judge. But we have the judgment of the jury and the trial judge as to what is a proper amount for punishment, warning, and deterrence, and with some hesitation, we will allow the damages to stand as fixed by the circuit judge." Id. at 240,147 N.W. at 20.

${ }^{88}$ The following explanatory "comment" appears in the Restatement of Torts on the subject of punitive damages. "The awarding of punitive damages is not prevented by a prior criminal conviction for the same act, which is relevant only to the amount of the award ...." $\S 908$ at 554. The comment of the court in Eshelman v. Rawalt, 298 111. 192, 198, 131 N.E. 675,678 (1921), in reversing an award for punitive-exemplary damages, merits attention: "The damages allowed, however, are very large, indeed, [\$13,500, mainly as punitive-exemplary damages] and far beyond any punishment inflicted by the Criminal Code for the crime of adultery, which is a fine of a limited amount or a jail sentence. It is true that the Criminal Code does not control the questions, but there is no distinction between exemplary damages and damages allowed as a punishment, ... and the Criminal Code fixes a punishment designed to be adequate to prevent the offense for the protection of society."

89 It has been suggested that a joinder of actions might obviate that undesirable result. Morris, supra note 2, at 1194, 1209.

90 I SEDGwICK 736. "But a principal or master, though he may be liable for actual damages arising from the willful or wanton act of his agent or servant, may not be mulcted in 
The court's prolix charge in the Russell case on the liability of the union for the acts of its "agents" was extremely general and abstruse. To the jury, such abstractions must have been an impenetrable thicket. What, if anything, the jury could make of it is very questionable. That the award reflected an understanding of the subtle principles involved in the charge is open to grave doubt.

Moreover, the judge failed to charge the jury that the "burden of showing authorization or approval by the principal is on the plaintiff." 91 This is not a perfunctory omission; such a burden is dictated by experience. 92 To elicit the truth about the activities and motives of men in a strike is one of the most difficult tasks assigned to courts. Industrial relations disputes generate the most sensitive contact between law and emotion. Tempers are frayed and feelings are at a high pitch. In a strike, "feelings on both sides are necessarily wrought up, and the desire for victory is likely to obscure nice moral questions and poison the minds of men by prejudice."93 So spoke one of the most perceptive judges who graced the federal bench.

All that has just been said about the difficulties and the burden of proof resting on the plaintiff is particularly intensified in the realm of punitive-exemplary damages. When juries may permit personal quirks to intrude, not to mention prejudice, then it is especially important for courts themselves to look to the quality and genuineness of the proof. 94 Merely being "reasonably satis-

exemplary or punitive damages, unless he has either authorized or ratified that act." WILLISTON, CONTRACTS $\$ 1340$ (Rev. ed. 1937). For a contrary view, see Note, 70 HARV. L. Rev. 517,526 (1957). The author of the foregoing Note, however, points out that the jury "should be carefully instructed to exclude from consideration all factors except those needed to achieve the purpose of deterrence." Ibid. Where can one find such primordially pure jurors? The rule of respondeat superior is applied to punitive-exemplary damages in many jurisdictions. MCCORMICK 284. McCormick seems to justify the rule on two grounds: (1) "workable simplicity," and (2) the plaintiff's difficulty in showing wrong doing by "those higher up." Id. at 285. An ironical situation results. An anomalous doctrine is introduced into the law; it is then extended without justification because of the difficulty of proof in the particular instance. Thus anomalies proceed from one to another.

91 Record, pp. 626-30. The trial judge charged that "it is not necessary ... that the agent's authority should be expressly conferred or that the act complained of should have been ratified." Id. at 626 . All that the judge requested in his charge was that the jury be "reasonably satisfied." The Alabama Supreme Court said that "there need be only a scintilla of evidence to require reference of the issue raised thereby [presumably the complaint] to the jury." 264 Ala. 456, 468, 88 So.2d 175, 185 (1956).

92 "Too great caution cannot be exercised in permitting the recovery of punitive damages for the willful or reckless act of a servant not authorized or approved by the master. The rule that permits a recovery in such cases is a harsh one, and the plainest principles of justice call for caution in its application ...." Funk v. Kerbaugh, 222 Pa. 18, 20, 70 N.E. 953, 954 (1908). Since the necessity for that caution was not articulated by the trial judge in the Russell case, such caution was not, in all probability, observed by the jury.

93 Great Northern Ry. v. Brosseau, 286 Fed. 414, 416 (D.N.D. 1923) (per Amidon, J.).

94 Courts "ought to exercise a high degree of watchfulness to prevent [the doctrine of punitive-exemplary damages] from being perverted and extended beyond the real principles upon which it is based ...." Eshelman v. Rawalt, 298 Ill. 192, 197, 131 N.E. 675, 677 (1921). 
fied," as the court instructed the jury in the Russell case, may not be enough for such awards. Anything less than clear proof fully sustaining the plaintiff's burden may result in juries awarding punitive-exemplary damages when they are more interested in keeping unions out of the area than in rendering a fair judgment on the facts. There may be shades of opinion as to the social utility of trade unions in our society. There is little, if any, basis to warrant endowing local ad hoc juries with the power to decide whether unions may function freely or under potentially harsh handicaps. This is a matter of serious legislative policy for the Congress of the United States to decide and local juries should not be permitted to arrogate to themselves that right under the guise of awarding punitive-exemplary damages. Such a doctrine can scarcely be said to contribute to stability in our society.

It has been said that our "underlying philosophies of liability are in a state of flux." 95 In those circumstances, it is appropriate to inquire whether the doctrine of punitive-exemplary damages justifies itself. There is not much evidence that juries can exercise and utilize this device with proper responsibility, clarity, or detachment. The role of bias and caprice might be dangerously elevated. A defendant can become a helpless prey and a sport of prejudice. Violating modern social needs, the doctrine encourages complex neurotic disturbances instead of desensitizing them. It does not submit itself to reasonable discipline demanded by legal process. The exceptional cases in which compensatory damages are slight but the need for imposing liability on a defendant is exigent may be dealt with by requiring the defendant to pay all plaintiff's legal costs and expenses.

A distinguished philosopher said: "To be ruled by a judge is, to the extent that he is not bound by law, tyranny or despotism." 96 How much more tyrannous and despotic is it to be subject to the undisciplined rule of juries which the doctrine of punitive-exemplary damages legalizes.

If the doctrine is to be continued, stringent efforts should be made to make such awards as scientific as possible. The cloak of sanctity should be removed from awards that often are begrimed with conscious and unconscious prejudice. They should be based on the maximum information available respecting

952 HARPER \& JAMES, TORTS 1232 (1956). The following statement from a staunch supporter of the doctrine is worth noting: "If it had been practicable for the judges to analyze and define for the jury with precision all the elements of legal harm which enter into every case, there would have been no necessity for the recognition of the idea of punishment as a proper end in the administration of the law of civil wrong. But they did not essay this task and it was felt that the jury should be left to deal with the undefined factors of harm with a pretty free hand. The doctrine of exemplary damages answered this end well enough for practical purposes and hence gained currency. As our theory of wrong catches up with the law of damages, the idea of punishment will appear more and more out of place in the civil system, and it may possibly in time altogether disappear." STREET, op. cit. supra note 51, at 488 .

96 Cohen, Reason and Nature 420 (1931). See Holmes, Collected Legal Papers 129 (1920). See also COHEN, op. cit. supra at 421. 
the relationship of punishment to deterrence. That is the tendency in criminal law today, ${ }^{97}$ and it should certainly be extended to civil proceedings. If the problem is hopeless, then the Connecticut rule should be adopted. In any event, the doctrine should not be extended to labor relations cases. Since strikes present particularly serious difficulties of proof, inter alia, as to agency and provocation, and since the doctrine is studded with so many anomalies and incongruities, the abandonment of the doctrine in labor relations cases might well be justified, at least in the interest of "workable simplicity."98 Otherwise, the doctrine will only exacerbate labor-management relations and threaten stability in our society. There may still be an adequate residuum of admonition in compensatory damages to serve the legitimate aims of tort liability.

97 See Economist, November 11, 1961, p. 532.

98 See note 90 supra. 